\title{
A Review of Sustainable Management of Mine Tailings
}

\author{
ALI A. Mahmood ${ }^{1 a}$ and MARIA Elektorowicz ${ }^{2 b}$ \\ ${ }^{1}$ Senior Lecturer, Dept. of Civil Engineering, University College of Technology Sarawak, 868 \\ Persiaran Brooke, 96000 Sibu, Sarawak, Malaysia \\ ${ }^{2}$ Professor, Dept. of Building Civil and Environmental Engineering, Concordia University, Rm: \\ EV-6.213, 1455 De Maisonneuve Blvd. W., Montreal, Quebec, H3G 1M8, Canada
}

aali.mahmood@ucts.edu.my, ${ }^{b}$ mariae@encs.concordia.ca

Keywords: Mine tailings, construction, roads

\begin{abstract}
This paper summarizes research done on mine tailings management and explores new trends in the sustainable re-use of these tailings in construction activities. It is concluded that no research to date had addressed the issue of using hardened mine tailings as construction materials for temporary access unpaved roads in cold climates.
\end{abstract}

\section{Introduction}

Tailings are the waste materials (byproducts) of the mining industry. The tailings contain all other constituents of the ore but the extracted metal, among them heavy metals and other toxic substances that are either added to the tailings in the milling process or available with the ore before that [1].

Most of the mill tailings mass-produced worldwide are dumped in large surface impoundments [2]. The embankments forming these impoundments are earth fill dams. Over the years these earth fill dams have had several serious failures some even fatal. An example of the disasters originating from tailings dams failures is the Merriespruit dam tailings failure that resulted in the deaths of 17 people and extensive damages to a residential township in South Africa in 1994 [3,4]. Another disaster took place in the Philippines in 2002 were tailings spilled into Mapanuepe Lake and eventually into the Saint Tomas river. Low lying villages were flooded with mine waste. At least 250 families were evacuated from that area.

Therefore, it is necessary to devise another approach for the storage and disposal of mine tailings with the aim of eliminating the hazards and risks associated with mine tailings dams. Research on mine tailings stems from the necessity to prevent the danger posed by mine tailings to the environment. This danger is characterized by the tendency of mine tailings to release acids and heavy metals once in contact with oxygen and water [5].

This paper is a review of recent practice in the sustainable management of mine tailings and their use as construction materials and additives. New directions will be presented in the current research practice on mine tailings engineering.

\section{Solidification/Stabilization}

Stabilization is defined as a process where additives are mixed with waste to minimize the rate of contaminant migration from the waste and to reduce the toxicity of the waste [6]. With reference to the nature of the solidification chemicals used, solidification systems are of two basic types, inorganic or organic [7]. The most important inorganic solidification systems used are the following [8]: Portland cement, lime/fly Ash, kiln dust (lime and cement), Portland cement/fly ash, Portland cement/lime, Portland cement/sodium silicate.

Calsifrit ${ }^{\mathrm{TM}}$. Calsifrit ${ }^{\mathrm{TM}}$ is a totally amorphous material developed recently by novaFrit International. It is defined as a matrix of calcium and sodium fluoro-aluminosilicate. It is a homogenous solid substance possessing high reactivity potential and shows cementitious properties when ground to a fine powder [9]. Calsifrit ${ }^{\mathrm{TM}}$ is currently utilized as a concrete durability improver. A report published by the University of Sherbrook in Quebec stated that using 25\% 
Calsifrit ${ }^{\mathrm{TM}}$ to substitute for Portland cement decreased the permeability of concrete to chloride ion by $50 \%$. Calsifrit, it is explained, does this by promoting a discontinuous pore structure [9]. No research to date has been published on the utilization of this product in other industries

Calsifrit ${ }^{\mathrm{TM}}$ was chosen since it contains chemical components that aid and enhance binder materials setting. No researcher, to date, had attempted to investigate the effect of adding Calsifrit ${ }^{\mathrm{TM}}$ on the waste-binder system. Table 1 shows the chemical composition of Calsifrit ${ }^{\mathrm{TM}}$.

Table 1 Chemical composition of Calsifrit ${ }^{\mathrm{TM}}$

\begin{tabular}{|c|c|c|c|c|c|c|}
\hline Carbon & $\mathbf{F e}_{2} \mathbf{O}_{3}$ & $\mathrm{Na}_{2} \mathbf{O}$ & $\mathbf{C a F}_{2}$ & $\mathbf{C a O}$ & $\mathbf{A l}_{2} \mathbf{O}_{3}$ & $\mathbf{S i O}_{2}$ \\
\hline $3-5 \%$ & $2-3 \%$ & $10-14 \%$ & $16-20 \%$ & $5-8 \%$ & $18-22 \%$ & $37-43 \%$ \\
\hline
\end{tabular}

\section{Mine Tailings as Construction Materials}

Success in the process and results of mine tailings hardening led researchers to further think the possibility of using these hardened tailings in the construction industry thereby utilizing a vastly available untapped resource and hindering, albeit to a certain extent, the harmful effects of unprocessed tailings on the environment. This success coupled with historical evidence that told of using tailings in the mine backfilling business further strengthened this new approach.

The earliest reported use of mine tailings as a construction material was its use as a mine backfill material. Use of mine tailings for backfilling started in the early years of the potash industry by use of dry and wet residues [10]. Different technologies were developed in the last 80 years. One of these, the slurry backfill technology is considered a very efficient backfill method, because of its combination of tailings and brine disposal. Since 1908, the slurry backfill technology has been successfully practiced in the German potash industry, especially in flat-lying deposits of the South Harz potash district [10].

Success in these early attempts led researchers to attempt a thorough investigation approach of mine backfilling using more advanced technologies and methods. Garand et al. [11] discussed the effects of flocculent deposition of tailings sludge in the Bouchard-Hebert mine in northern Quebec. The flocculent PERCOL E-10 was added to the tailings sludge before it was mechanically thickened in the paste backfill plant. These flocs showed grain size distribution larger than or similar to coarse silt. The authors stated that the beaches formed with these flocs could be used as competent foundation material for upstream raises [11]. This study presented a modification on Robinsky's thickening principle [12] by adding a flocculent to the tailings to enhance thickening and increase stability.

Another study by Benzaazoua et al. [13] investigated in some detail the influence that several chemical factors have on the performance of mine sulphidic paste backfill. They used four samples from three different mines located in Canada, which were mixed with four types of binders and six different types of mixing water chemical characteristics. It was found that the mixing water is an important parameter that affects the quality of the paste backfill mass and that, in contrast to the Portland cement based binder, slag-based binder hydration seems to be inhibited by the presence of soluble sulphates [13]. The results of this study clearly demonstrated the inefficiency of choosing paste backfill mixtures without testing first the tailings and mixing water characteristics.

Theriault et al. [14] described the surface disposal of paste tailings at the Bulyanhulu Gold mine in Tanzania. The tailings slurry was dewatered before transportation to the paste plant where process water was added in the paste conditioner to produce a paste of the desired consistency. The authors affirmed that the cycling of the tailings deposition in thin layers has been successful in generating a stable paste stack. It was concluded that paste stack can be engineered to meet the required geotechnical and environmental objectives.

These earlier studies ascertained the applicability of using mine tailings as backfill materials and encouraged investigation of the use of mine tailings for other construction disciplines. One such discipline is exemplified by the work of Demers and Haile [15] who described the stabilization of 
zinc tailings (called Jarosite). Jarosite was deposited in ponds sustained by clay dykes until 1998 . Since then, Jarosite was thickened first using vacuum filters and then lime, cement and water were added to the thickened Jarosite to make a product that was termed Jarofix. It was observed that cured Jarofix was an excellent fill material for raising the containment dykes. The research was carried out inside the tailings storage facility and limited testing was done in this case.

Another different example lies in the work of Zou and Sahito [16] who studied the applicability of using a new type of binder termed HiFa Bond for shotcreting in underground support. The authors used mine tailings as aggregate in shotcrete. These tailings were mixed with sand, polymer and steel fibers. Test results showed that mine tailings have potential for shotcreting for underground support.

Meanwhile, Celik et al. [17] investigated the effects of the mineralogical composition and chemical properties of gold tailings on the compressive strength of Ordinary Portland Cement. The authors used silica fume and 2 types of fly ash, with the tailings as Portland cement additives. It was shown that the compressive strength values of mortars prepared by these additives were acceptable as they were within the range of European standards. The authors presented the conclusion that the gold tailings could be used as an additive in Portland cement production. No weathering resistance or leaching testing had been done in this study.

Another study by Roy at al. [18] investigated the use of gold tailings in making bricks. The authors mixed the tailings with 4 types of soil and Portland cement. The study showed that soiltailings bricks passed the required criteria defined by means of compressive strength, linear shrinkage and water absorption. The cost of producing these tailings-soil bricks was shown to be less than that of traditional clay bricks. However, there were no leaching or weathering environmental tests conducted.

Swami et al. [19] investigated the use of Kimberlite diamond mine tailings in road layers. For this purpose, the authors carried out a field and laboratory testing program. The field experiments consisted of construction of a test road section using these tailings, which were evaluated for use in sub-base, base and wearing courses. It was shown that Kimberlite tailings could be used in cement bound sub-bases. The study did present a new approach in the area of road construction. However, the testing regime implemented was not comprehensive and there were no weathering resistance or leaching tests conducted. These tests are considered essential in cold environments such as that of Canada. Also the experimental program lacked correlation with numerical analysis techniques.

Other researchers like Fall et al. [20], Fall et al. [21], Benzaazoua et al. [22], Ercikdi et al. [23], Fall and Pokharel [24] and Helinski et al. [25] investigated the use of mine tailings in the most traditional manner by using them as cemented paste backfill. Meanwhile, the research group of Yang et al. [26] investigated the use of mine tailings in the glass-ceramic/ceramic tile industry.

\section{Concluding Remarks}

It appears from the above that although several research studies discussed the applicability of using mine tailings in several types of construction practices, none had comprehensively addressed the issue of using mine tailings as construction materials for temporary access unpaved roads in cold climates. Simulation of the strength and weathering properties of these tailings using a powerful numerical technique was lacking in these studies, as well.

It is also concluded that no research study had comprehensively addressed the following issues:

1) Determining the unconfined compressive strength and weathering characteristics of several types of Portland cement-fly ash-slag stabilized/solidified Canadian mine tailings,

2) Investigating the suitability and effect of using Calsifrit ${ }^{\mathrm{TM}}$ on the properties of the mine tailings-binder combinations,

3) Determining the freezing/thawing and wetting/drying resistance of hardened tailings,

4) Simulating the strength and weathering characteristics of the hardened tailings using a powerful numerical technique. 


\section{Acknowledgment}

The authors would like to acknowledge with gratitude the support that Dr. Michelle Nokken and Dr. Catherine Mulligan of Concordia University (Montreal, Canada) have provided for this study.

\section{References}

[1] ICOLD (2003). International Commission on Large Dams. Report. 151 Boulevard Haussmann, 75008 Paris, France.

[2] T. Simieritsch, J. Obad and S. Dyer (2009). Tailings plan review- an assessment of oil sands company submissions for compliance with ERCB Directive 074: tailings performance criteria and requirements for oil sands mining schemes. Pembina Institute, Box 7558, Drayton Valley, Alberta, T7A 1 S7.

[3] A.B. Fourie, G. Papageorgiou, Defining an appropriate steady state line for Merriespruit gold tailings. Canadian Geotechnical Journal, 38(4) (2001) 695-706.

[4] A.B. Fourie, G.E. Blight and G. Papageorgiou, Static liquefaction as a possible explanation for the Merriespruit tailings dam failure. Canadian Geotechnical Journal, 38(4) (2001) 707-719.

[5] R. Gautam, E.K. Yanful, and D.G. Karamanev, Laboratory scale sulphide tailings oxidation. In Proceedings of the $53^{\text {rd }}$ Canadian Geotechnical Conference, Canadian Geotechnical Society. 15-18 October (2000). Montreal, Quebec. pp. 649-656.

[6] M.D. LaGrega, P.L. Buckingham and J.C. Evans (1994). Hazardous waste management. McGraw-Hill, Inc., New York.

[7] J.R. Conner, Ultimate disposal of liquid wastes by chemical fixation. In Proceedings of the $29^{\text {th }}$ Annual Purdue Industrial Waste Conference. Purdue University, West Lafayette, Indiana. (1974) pp. 906-922.

[8] J. Conner (1990). Chemical fixation and solidification of hazardous wastes. Van Nostrand Reinhold, New York.

[9] NovaFrit International. (2006). 1200 Garnier Street, Ville Ste-Catherine, Quebec, J0L 1E0.

[10] S. Wasayo (2003). Suitability of mine tailings for shotcrete as a ground support. M.A.Sc. thesis, Mining Engineering, Dalhousie University, Halifax, Nova Scotia.

[11] P. Garand, S. Vezina and K. Bocking, Effects of flocculent on deposition of tailings sludge for upstream raise of impoundment dykes. In Proceedings of the $53^{\text {rd }}$ Canadian Geotechnical Conference, Canadian Geotechnical Society. 15-18 October (2000). Montreal, Quebec. pp. 633640.

[12] E. Robinsky, Tailings disposal by the thickened discharge method for improved economy and environmental control. Tailings Disposal Today, Vol. 2, pp. 75-92, 1979 by Miller Freeman Publications Inc., San Francisco, California. In Proceedings of the $2^{\text {nd }}$ International Tailings Symposium, May (1978). Denver, Colorado.

[13] M. Benzaazoua, T. Belem and B. Bussiere, Chemical factors that influence the performance of mine sulphidic paste backfill. Cement and Concrete Research, 32(7) (2002) 1133-1144.

[14] J.A. Theriault, J. Frostiak and D. Welch, Surface disposal of paste tailings at the Bulyanhulu gold mine, Tanzania. In Proceedings of Sudbury 2003 Mining and the Environment. 25-28 May (2003). Sudbury, Ontario. 
[15] B. Demers, G. Haile, Management of tailings stabilized by lime and cement at Canadian electrolytic zinc, Valleyfield, Quebec. In Proceedings of Sudbury 2003 Mining and the Environment. 25-28 May (2003), Sudbury, Ontario.

[16] D.H. Zou, W. Sahito, Suitability of mine tailings for shotcrete as a ground support. Canadian Journal of Civil Engineering, 31(4) (2004) 632-636.

[17] O. Celik, I.Y. Elbeyli and S. Piskin, Utilization of gold tailings as an additive in Portland cement. Waste Management and Research, 24(3) (2006) 215-224.

[18] S. Roy, G.R. Adhikari, and R.N. Gupta, Use of gold mill tailings in making bricks: a feasibility study. Waste Management and Research, 25(5) (2007) 475-482.

[19] R.K. Swami, N.K.S. Pundhir and S. Mathur, Kimberlite tailings a road construction material. Transportation Research Record: Journal of the Transportation Research Board, 2(1989) (2007) 131-134. Transportation Research Board of the National Academies, Washington, D.C.

[20] M. Fall, M. Benzaazoua and S. Ouellet, Experimental characterization of the influence of tailings fineness and density on the quality of cemented paste backfill. Minerals Engineering, 18(1) (2005) 41-44.

[21] M. Fall, M. Benzaazoua and E.G. Saa, Mix proportioning of underground cemented tailings backfill. Tunnelling and Underground Space Technology, 23(1) (2008) 80-90.

[22] M. Benzaazoua, B. Bussiere, I. Demers, M. Aubertin, E. Fried and A. Blier, Integrated mine tailings management by combining environmental desulphurization and cemented paste backfill: Application to mine Doyon, Quebec, Canada. Minerals Engineering, 21(4) (2008) 330-340.

[23] B. Ercikdi, A. Kesimal, F. Cihangir, H. Deveci and I. Alp, Cemented paste backfill of sulphide-rich tailings: importance of binder type and dosage. Cement and Concrete Composites, 31(4) (2009) 268-274.

[24] M. Fall, M. Pokharel Coupled effects of sulphate and temperature on the strength development of cemented tailings backfills: Portland cement-paste backfill. Cement and Concrete Composites, 32(10) (2010) 819-828.

[25] M. Helinski, M. Fahey and A. Fourie, Coupled two-dimensional finite element modeling of mine backfilling with cemented tailings. Canadian Geotechnical Journal, 47(11) (2010) 1187-1200.

[26] H. Yang, C. Chen, L. Pan, H. Lu, H. Sun and X. Hu Preparation of double-layer glassceramic/ceramic tile from bauxite tailings and red mud. Journal of the European Ceramic Society, 29(10) (2009) 1887-1894. 